\title{
THE FSW TECHNOLOGY OF NON-FERROUS METALS - PROCESS CONDITIONS AND EXAMPLES OF APPLICATION
}

\author{
A. PIETRAS, A. WĘGLOWSKA, B. RAMS \\ Institute of Welding, Polska. 44-100, Gliwice, Str. Bl. Czeslawa 16-18, Poland. E-mail: adam.pietras@is.gliwice.pl
}

\begin{abstract}
The paper presents welding conditions and the process of creating a FSW weld during welding elements made of wrought aluminium alloys and cast aluminium alloy. Investigations were conducted at Institute of Welding, Gliwice (Instytut Spawalnictwa), on the FSW stands equipped with vertical milling machine adapted for friction stir welding process. Influence of the tool's dimension and shapes on the plasticization process of welded material and formation of a weld behind the tool, at different welding set of parameters were studied. During the investigations it was noticed, that forces and torque occuring during FSW and stiffness of the clamping system influence the temperature of the welding area, the plasticity of the material, the particles fragmentation and the quality of the joints. On the basis of research correct welding conditions were selected and process of welding was conduct using specially designed instrumentation. The views of exemplary friction stir welded elements and macrosections from the welding areas are shown. 14 Ref., 4 Tabl., 16 Fig.
\end{abstract}

Keywords: friction stir welding, wrought and cast aluminium alloys, copper tool

\section{Introduction}

FSW (Friction Stir Welding) is the method that makes it possible to successfully join aluminium alloys, including casting alloys and copper alloys, which are difficult to weld using known welding techniques. This method is increasingly used in the world mainly in the shipbuilding, rail, automotive and building industries.

In FSW process the stirring and rotating tool penetrating material along the line of welding is applied for the friction heating and softening of the material. After the tool is put into rotation and frictional heating is softening the material around the probe, the tool is traversed along the joint line. The heated and plasticised materials of the components being welded are extruded around the tool probe backwards, where before cooling down they are stirred and upset by the shoulder. In the centre of the weld the zone called «nugget» is formed behind the tool in the result of the stirring of the softened metals of both parts being welded $[1,2]$.

The shape and dimensions of the weld depend on the shape and size of the stirring tool and applied welding parameters. The tool penetrating welding zone has three basic functions: heating metal in the area of joining, stirring of materials and upsetting of plasticised metal behind the tool in the phase of weld forming. Basic parameters of FSW process comprise:

- tool rotation speed $-\omega\left[\mathrm{mm}^{-1}\right]$,

- welding speed $-\mathrm{V}_{\mathrm{zg}}[\mathrm{mm} / \mathrm{min}]$,

- tilt angle $-\alpha\left[^{\circ}\right]$,

- tool type and size of the tool: probe diameter $\mathrm{d}[\mathrm{mm}]$, shoulder diameter - D [mm], probe length $-1[\mathrm{~mm}]$.

During FSW process, material of the workpiece subjected to mechanical stirring and intensive plastic deformation at higher temperature, spreads out also outside the stirring zone (thermomechanicaly affected zone). Additionally, the significant temperature gradient occurs across the weld

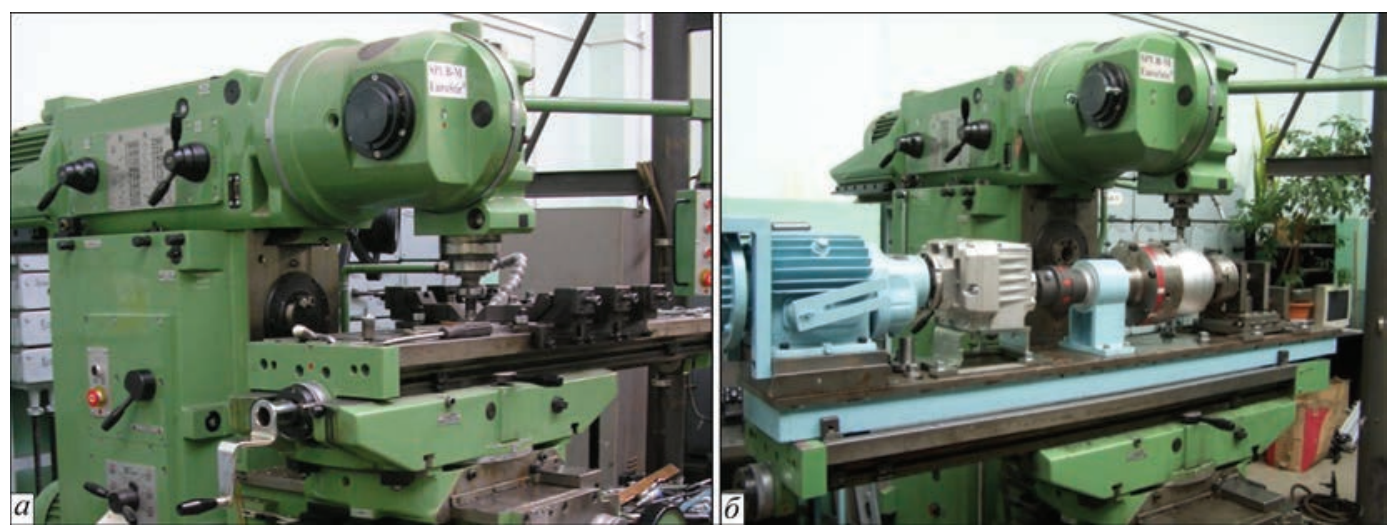

Fig. 1. Station for FSW welding process: $\mathrm{a}$ - tooling for plate welding; $\mathrm{b}$ - tooling for cylindrical elements 
outside the thermomechanicaly affected zone (in the heat affected zone). As the result of those factors more complex structure is being formed in the cross-section of the weld, which influences directly its mechanical properties [3-5]. In case of aluminium casting alloys welding, the changes in the microstructure are associated both with processes of deforming, recovery and recrystallization and also with microstructure component phase changes, e.g. with precipitation or dissolving of intermetallic phases [6]. The aim of this research was finding the relation between welding conditions: welding parameters, a tool shape, the process of forming of friction welded joint and welding quality.

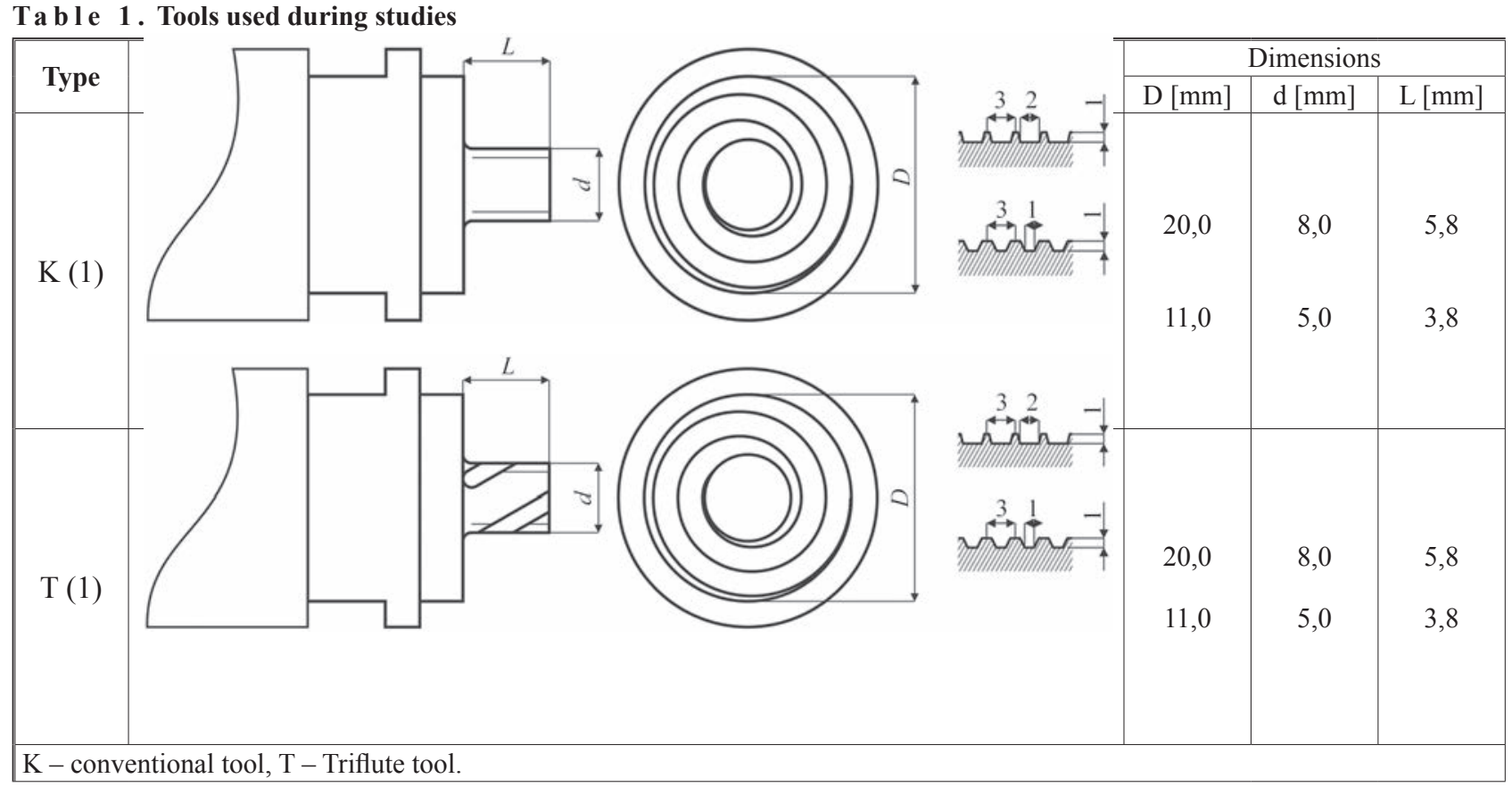

\section{Research station}

The investigation into $\mathrm{FSW}$ process was conducted at Instytut Spawalnictwa on the vertical milling machine FYF32JU2 equipped with special of cylindrical or spherical elements, equipped with a special positioner. Some of the testing was conducted on the station build on the basis of numerical milling machine FNC 50NC.

\section{Tools}

During research, the impact of several tools having different shapes and dimensions of working parts, on the process and welding quality was tested for various configuration of components being welded. The tools were made of high-speed steel S 6-5-2 [7]. The shapes and dimensions of the tools used in research are shown in Table 1.

Ta b le 2 . Chemical composition of aluminium alloys used during studies $[8,9]$

\begin{tabular}{|c|c|c|c|c|c|c|c|c|c|c|c|}
\hline \multirow{2}{*}{ No. } & \multicolumn{2}{|c|}{ Alloy denotation } & \multicolumn{9}{|c|}{ Content of chemical elements, $\%$} \\
\hline & numerical & chemical symbol & $\mathrm{Si}$ & $\mathrm{Cu}$ & $\mathrm{Mg}$ & $\mathrm{Mn}$ & $\mathrm{Fe}$ & $\mathrm{Ti}$ & $\mathrm{Zn}$ & $\mathrm{Ni}$ & $\mathrm{Al}$ \\
\hline 1 & $\begin{array}{l}\text { EN AC-43200 } \\
\text { (AK9)* }\end{array}$ & EN AC-Al Sil0Mg(Cu) & $9,00-11,00$ & 0,35 & $0,20-0,45$ & 0,55 & 0,65 & 0,20 & 0,35 & 0,15 & rest \\
\hline 2 & $\begin{array}{l}\text { EN AW-2017A } \\
\text { (PA6)** }\end{array}$ & EN AW-Al Cu4MgSi & $0,20-0,80$ & $3,50-4,50$ & $0,40-1,00$ & $0,40-1,00$ & 0,70 & 0,15 & 0,25 & - & rest \\
\hline 3 & EN AW-6082 (PA4) & EN AW-Al SiMgMn & $0,70-1,30$ & 0,10 & $0,60-1,20$ & $0,40-1,00$ & 0,50 & 0,10 & 0,20 & - & rest \\
\hline
\end{tabular}

clamps fixing the welded parts and special ISstir head constructed at Instytut Spawalnictwa for the measuring of torque and friction force. The station for testing of linear welding of plates is shown in Fig. 1a, while Fig. 1b presents the station for welding

\section{Tested material}

During FSW, forces and weld forming process were tested for wrought aluminium alloys, casting alloy and copper M1. Chemical composition of aluminium alloys used in the research is presented in Table 2.

\section{Research into FSW process}

Testing of the tool effect on welding quality 
Table 3. Welding parameters

\begin{tabular}{||c|c|c|c|l|}
\hline \multirow{2}{*}{ Parameter no. } & \multirow{2}{*}{$\begin{array}{c}\text { Material from } \\
\text { advancing side }\end{array}$} & \multicolumn{2}{|c|}{ Tool movement parameters } & \multirow{2}{*}{ Notes } \\
\cline { 3 - 4 } & $\omega\left[\mathrm{min}^{-1}\right]$ & Vzg $[\mathrm{mm} / \mathrm{min}]$ & \\
\hline 1 & EN AC-43200 & 560 & 280 & Correct weld face. Linear discontinuity \\
\hline 3 & EN AC-43200 & 900 & 180 & Correct weld face and structure \\
\hline 6 & EN AW-2017A & 560 & 280 & Correct weld face. Linear discontinuity \\
\hline 9 & EN AW-2017A & 450 & 560 & Correct weld face and structure. Very small imperfections \\
\hline 10 & EN AW-2017A & 900 & 560 & Correct weld face. Linear discontinuity \\
\hline 11 & EN AW-2017A & 560 & 280 & Uneven weld surface. Correct weld structure \\
\hline 14 & EN AW-2017A & 450 & 180 & Correct weld face and structure \\
\hline 15 & EN AW-2017A & 900 & 560 & Correct weld face. Linear discontinuity \\
\hline 16 & EN AC-43200 & 900 & 180 & Correct weld face. Linear discontinuity \\
\hline 19 & EN AC-43200 & 900 & 560 & Incorrect weld material stirring. Large wormhole cavity \\
\hline
\end{tabular}

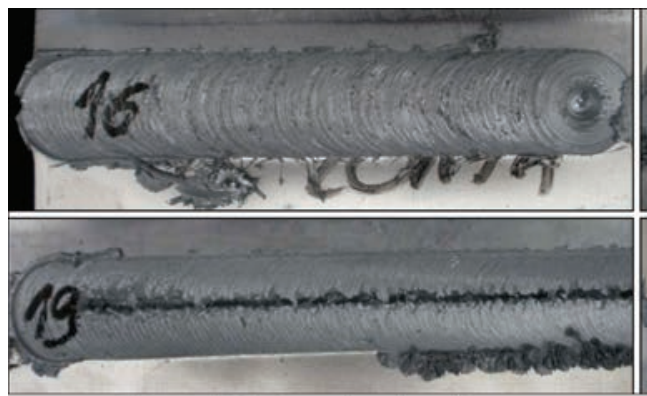

EN AC -43200 from advancing side

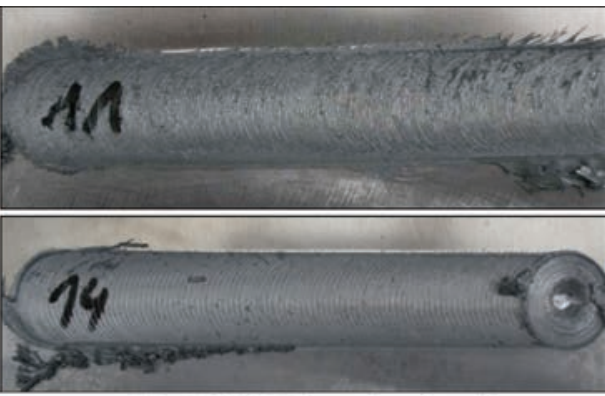

EN AW-2017A from advancing side

Fig. 2. View of the surfaces of the selected welds EN AC-43200 + EN AW-2017A obtained for various process parameters

Research into the influence of tool shape and dimensions on FSW quality was conducted using tools for various welding parameters, enumerated in Table 1. Tests were conducted for wrought aluminium alloys, casting alloys, copper M1 as well as wrought alloy welded together with casting alloy. Obtainment of the correct weld is difficult, in particular in case of welding of dissimilar materials. Selected sets of parameters used while welding of wrought alloy EN AW-2017A + casting alloy EN AC-43200 are shown in Table 3.
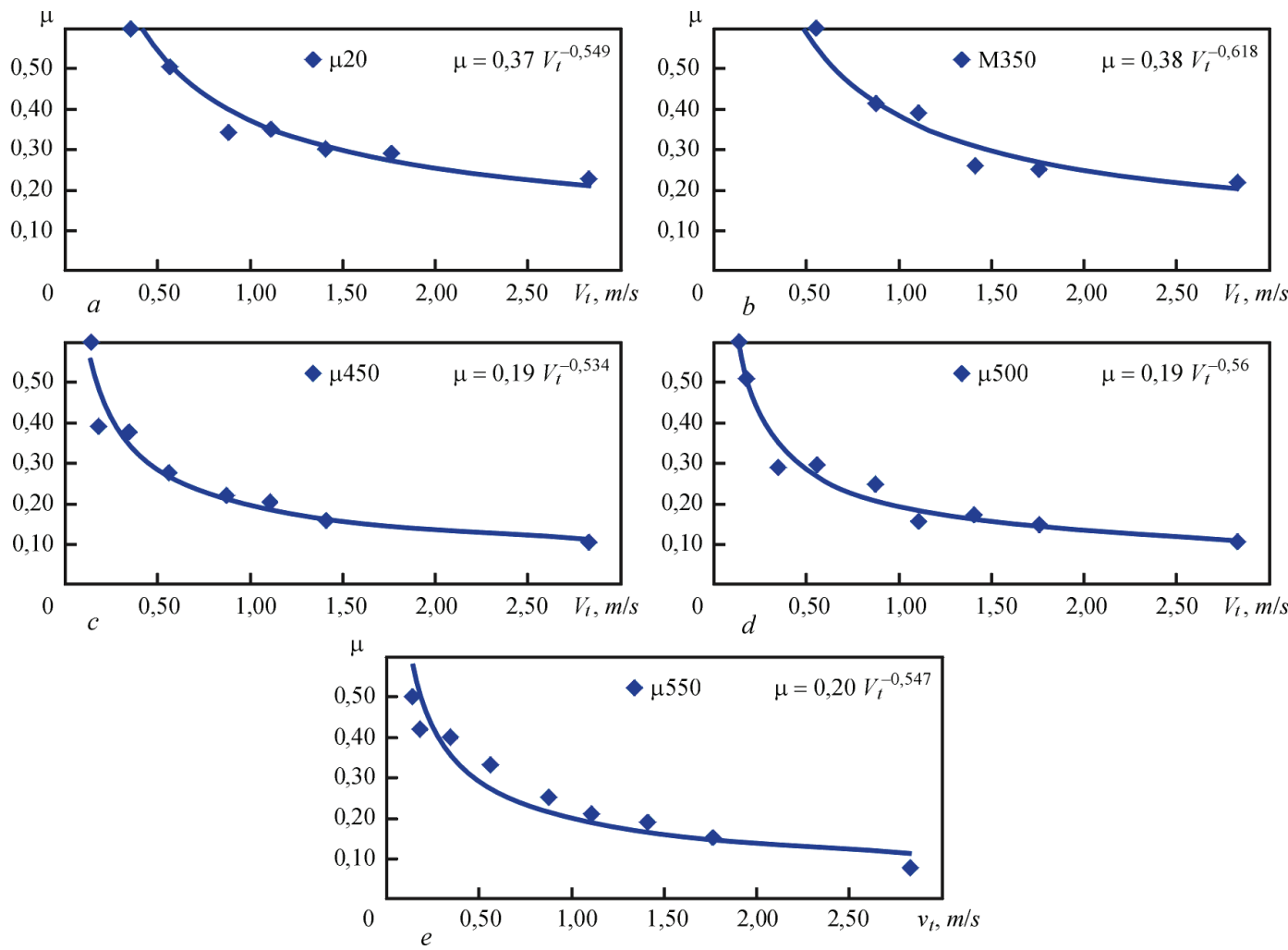

Fig. 3. The change of friction coefficient depending on friction speed at various temperatures: $\mathrm{a}-20^{\circ} \mathrm{C} ; \mathrm{b}-350{ }^{\circ} \mathrm{C} ; \mathrm{c}-450{ }^{\circ} \mathrm{C}$; $\mathrm{d}-500^{\circ} \mathrm{C}$; $\mathrm{e}-550^{\circ} \mathrm{C}[10]$ 


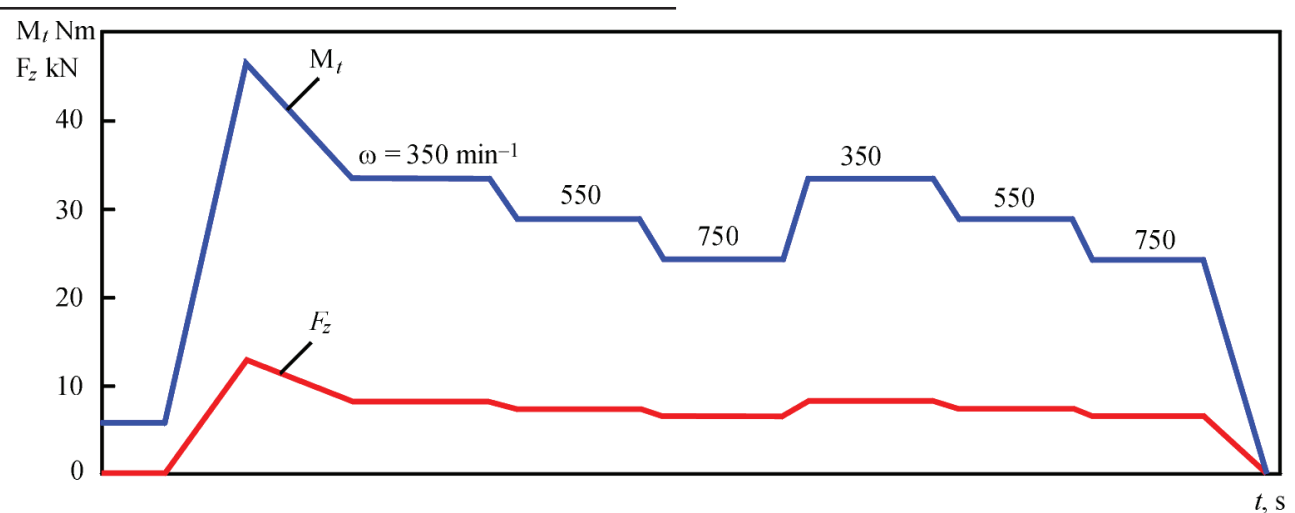

Fig. 4. Diagram of changes of friction torque $\mathrm{M}_{\mathrm{t}}$ and down force $\mathrm{F}_{\mathrm{z}}$ during testing of welding process with changing of frictional rotation speed of a tool [10]

During testing the process of weld face forming, material subjected to the strains and deformations, quality of the surface and weld structure were analysed. The example of a weld surface is shown in Fig. 2.

\section{Testing of friction forces}

In FSW process the change of mechanical energy into friction heat occurs, what makes it possible to create the conditions for welding in solid state. In this case the coefficient of friction between the tool metal and the welded plates surface is essential.

During the first stage of research into the friction phenomenon in the FSW process the impact of friction speed on friction coefficient was tested. Aluminium plates were initially preheated up to the temperature of: $350{ }^{\circ} \mathrm{C}, 450{ }^{\circ} \mathrm{C}, 500^{\circ} \mathrm{C}$ and $550^{\circ} \mathrm{C}$, i.e. up to the temperature occurring in the FSW process. While measuring, the tool having a pipe shape in the working part was pressed down to the plate surface and the down force and friction torque

Ta b l e 4. Results of measuring friction torque and down force recorded while testing of FSW using preheated plates [10]

\begin{tabular}{||c|c|c|c|c|}
\hline $\begin{array}{c}\text { Measure } \\
\text { No. }\end{array}$ & $\begin{array}{c}\text { Temperature } \\
\text { of plates prior } \\
\text { to the process, } \\
{ }^{\circ} \mathrm{C}\end{array}$ & $\begin{array}{c}\text { Tool rotation } \\
\text { speed } \omega, \mathrm{min}^{-1}\end{array}$ & $\begin{array}{c}\text { Friction } \\
\text { torque } \\
\mathrm{M}_{\mathrm{t}}, \mathrm{Nm}\end{array}$ & $\begin{array}{c}\text { Down } \\
\text { force } \\
\mathrm{F}_{\mathrm{z}}, \mathrm{kN}\end{array}$ \\
\hline 1 & 20 & 350 & 35,4 & 8,7 \\
\hline 2 & 20 & 550 & 30,5 & 7,8 \\
\hline 3 & 20 & 750 & 25,7 & 6,9 \\
\hline 4 & 20 & 350 & 37,1 & 9,0 \\
\hline 5 & 20 & 550 & 29,2 & 7,3 \\
\hline 6 & 20 & 750 & 25,1 & 7,1 \\
\hline 7 & 150 & 350 & 33,8 & 8,0 \\
\hline 8 & 150 & 550 & 29,0 & 6,9 \\
\hline 9 & 150 & 750 & 23,4 & 6,6 \\
\hline 10 & 150 & 350 & 33,7 & 7,7 \\
\hline 11 & 150 & 550 & 28,0 & 6,8 \\
\hline 12 & 150 & 750 & 24,8 & 6,7 \\
\hline 13 & 250 & 350 & 35,1 & 8,3 \\
\hline 14 & 250 & 550 & 27,4 & 6,9 \\
\hline 15 & 250 & 750 & 22,8 & 6,3 \\
\hline 16 & 250 & 350 & 33,8 & 7,7 \\
\hline 17 & 250 & 550 & 26,9 & 6,7 \\
\hline 18 & 250 & 750 & 23,1 & 6,6 \\
\hline & & & & \\
\hline
\end{tabular}

for different tool rates of rotation were measured. The tool was made of the same tool steel as FSW tools. For the known geometrical shapes of the tool and rotational speed, it is possible to calculate the distribution of friction coefficient depending on frictional speed for various temperatures of preheated plates. The tests were conducted on the numerically controlled station (build on the basis of milling machine FNC 50NC) at the same times of approaching and retracting the tool $\left(\mathrm{t}_{\mathrm{wst}}=3.0 \mathrm{~s}\right)$ and the same friction time $t_{t}=1.0 \mathrm{~s}$.

The test results for EN AW-2017A alloy are presented in Fig. 3. For the remaining alloys being tested, the dependence of friction coefficient on friction speed was similar.

Similar research was conducted for FSW process in which a conventional tool, having a tool shoulder diameter $=11.0 \mathrm{~mm}$ and a probe diameter $=5.0 \mathrm{~mm}$, was used on $4 \mathrm{~mm}$ thick plates of EN AW-2017A alloy, and a tool rotational speed $\omega$ was being changed while welding speed $\mathrm{V}_{\mathrm{zg}}$ remained on the same level of $200 \mathrm{~mm} / \mathrm{min}$. During making of a single longitudinal weld, the sequence of three different rotational speeds was changed twice, as in Fig. $4\left(\omega=350 \mathrm{~min}^{-1}, 550 \mathrm{~min}^{-1}\right.$ and $\left.750 \mathrm{~min}^{-1}\right)$, while measuring down force and friction torque using ISstir head. After the production of the first weld, the plates have been heated to the temperature up to $150^{\circ} \mathrm{C}$ and the second welding cycle was performed with changing the rotational speed of a tool and then the plates were heated up to the temperature of $250{ }^{\circ} \mathrm{C}$ and the third welding cycle was done. The results of the measured friction torque and down force are presented in Table 4.

Testing of metal structure in the area of tool friction during FSW process

During this testing, friction torque (down force), that resulted from summarized frictional resistance coming from two sources was recorded. One of the source was external friction, i.e. from force of shearing micro-joints and irregularities in local friction points and second source was internal 


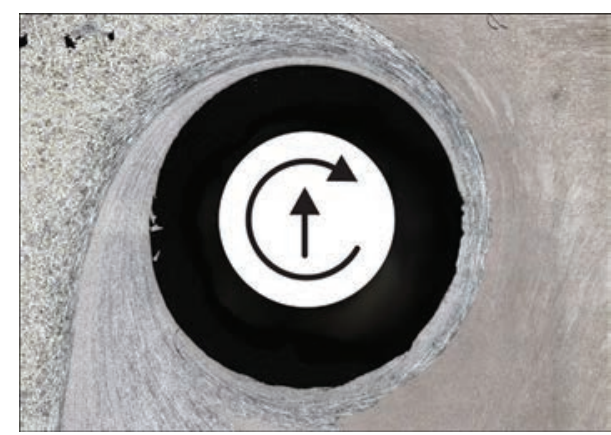

Fig. 5. Metal layers around a tool. Friction modified layer located in the direct vicinity of a probe. EN AW 6082 alloy from a retreating side (right side), EN AC 43200 alloy from advancing side (left side) extruded around a tool probe during FSW. The direction of rotation and translation movement of the tool is marked schematically

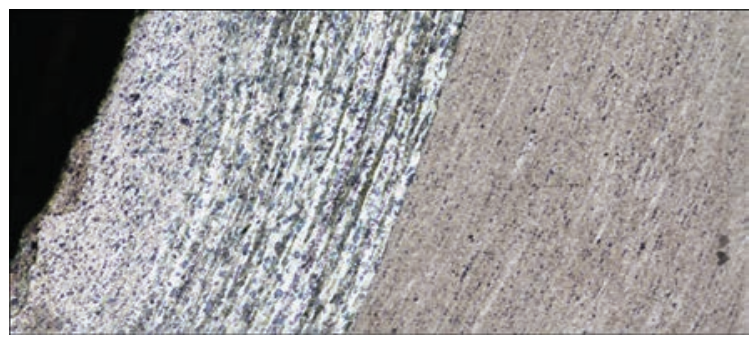

Fig. 6. Fragment of the modified layer of Fig. 5 on retreating side

friction, i.e. from forces connected with plastic strain of the metal layer up to the certain depth.

For samples undergoing friction both phenomena are clearly visible. During testing of friction coefficient and FSW process, it can be noticed that both friction forces and thickness of material layers undergoing plastic straining depend on friction speed. The structure of a layer being modified using friction is different from that of parent material. Fig. 5 and 6 shows metal deformed during the process in the area of a tool action. The area under observation includes a modified by friction layer of EN AC 43200 alloy in the cross-section parallel to the plane of welded plates, on the depth of $1 \mathrm{~mm}$, in the area of tool action after its retracting. Welded plates were of EN AC-43200 + EN AW-6082, $6.0 \mathrm{~mm}$ in thickness.

The image of the process of metal movement around a tool and creating a weld behind a tool observed from above (from a welding machine spindle) is shown in Fig. 7. Those images present cross-section of a weld made parallel to the surface of welded plates on the depth of $1.5,3.0$ and $4.5 \mathrm{~mm}$ below a tool shoulder, i.e. in the location of primary action of a tool probe. The shown image of a welding process has been obtained after adequate preparation of the samples in the place of rapid stoppage of a tool movement and retracting it from a weld region. The direction of rotation and translation movement of a tool is marked schematically in its position.

As can be seen in the above images, material is extruded around a tool on the retreating side, in accordance with the tool probe rotation. Along the tool probe the material from retreating side penetrates into the material from the advancing side on various depth. The observed image of the structure being created is obtained after stoppage of a translation movement and rapid retraction of a tool from the welding area.

Around the tool, on the retreating side, the material is moved backwards through a relatively wide area of plasticised layer towards the weld being created. This phenomenon is clearly visible at low tool rotational speeds (low friction speeds) which is accompanied by high friction forces. In the case of high tool rotational speeds (high friction speeds) the forces are noticeably lower and the thickness of a layer being modified is also lower (Fig. 8). Material is extruded backwards on retreating side, however is not deformed that strongly in large volume. Practically, at those high friction speeds only material from the front of a specimen is being moved backwards (in this case EN AC 43200). This phenomenon was clearly revealed while testing of FSW process using
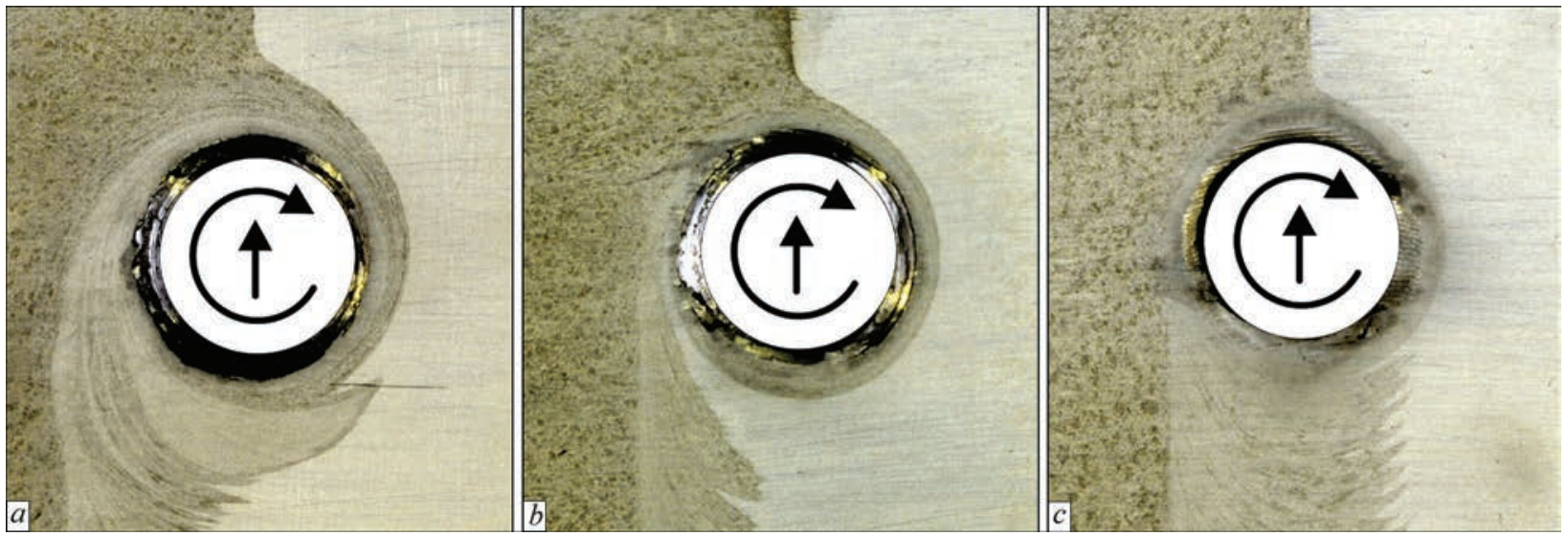

Fig. 7. The image of a weld formed around a tool, observed on the depth of: $\mathrm{a}-1.5 \mathrm{~mm} ; \mathrm{b}-3.0 \mathrm{~mm}$ and $\mathrm{c}-4.5 \mathrm{~mm}$ from weld face surface. From advancing side (left side) is located EN AC 43200 alloy, while from retreating side (right side) EN AW 6082 alloy. Welding parameters: $\omega=450 \mathrm{~min}^{-1} / \mathrm{V}_{\mathrm{zg}}=224 \mathrm{~mm} / \mathrm{min}$ 


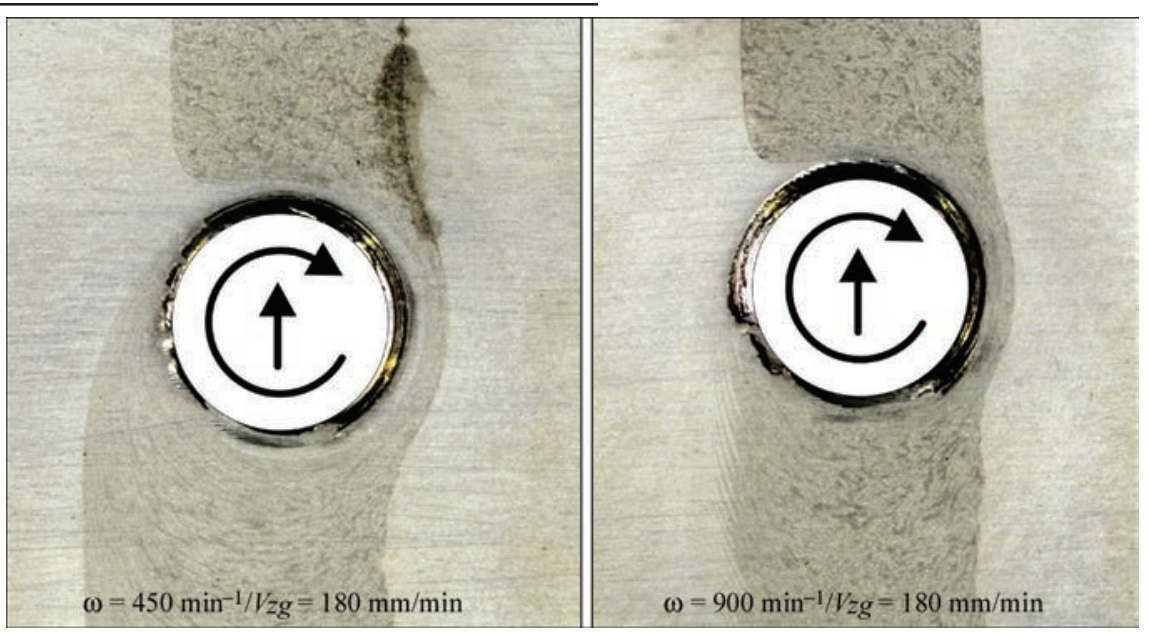

Fig. 8. A weld being created around the tool with implemented EN AC 43200 material of a tool probe width. Rotation of a tool and direction of the movement is marked in the photographs. On the right side: retracting, on the left side: advancing

EN AC 43200 material of tool probe width, being implemented into AW 6082.

As can be seen in Figs. 7 and 8, the thickness of the modified and plasticised layer during friction depends on the friction conditions and is of great significance during generating of friction heat. This friction modified layer takes part in the creation of a weld of specific structure and properties.

While welding material is extruded around a weld backwards, not changing its position behind the tool relative to the weld line. This phenomenon is clearly visible in the testing of FSW process using so called marker made of casting alloy. A rod of EN AC 43200 casting alloy having a dimensions of $3.0 \times 3.0 \mathrm{~mm}$ was included into the material of EN AW 6082 alloy, $6.0 \mathrm{~mm}$ thick, as in Fig. 9.
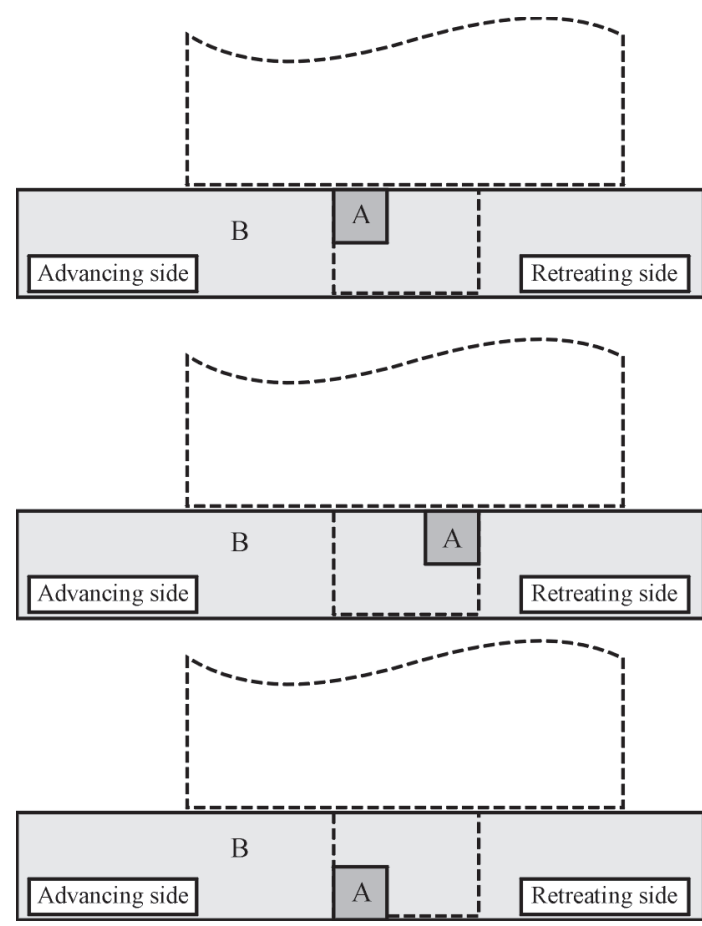

Fig. 9. Diagram of the distribution of a «marker» of EN AC 43200 alloy (A) in the material of EN AW 6082 alloy (B) before welding using FSW process
After welding, the location of the rod of EN AC 43200 is visible on the weld cross-sections in the separate welding areas. In case of location of a rod A on the advancing side before welding (Fig. 9a), during the process its material is moved around the tool and after welding is situated in a weld, as in Fig. 10.

As can be seen in the weld structure, despite extruding material through the narrow area around the tool, the EN AC 43200 alloy (material A) is located approximately in the same weld area as before the process completion.

In case of location of a rod on the retreating side before welding (Fig. 9b), during the process its material is moved around the tool and after welding is situated in a weld, as in Fig. 11. In case of location of a rod in the root area on the advancing side before welding (Fig. 9c) after welding the weld structure is obtained as shown in Fig. 12.

In spite of the fact that in welding process the material being implemented was strongly heated and deformed while extruding around the tool (as in Figs. 5 and 7) it successfully recreated its previous localisation. Dissimilar physical properties of materials do not prevent localisation of material is such a way after extruding around the tool.

Some molecules coming from the material being included can be moved in a random way and injected into the metal matrix, however in the whole mass the substantial part of the included material do not change its location after FSW completion. Such phenomenon occurs during welding with relatively low frictional speeds of a tool. For high rotational speeds, especially while using a tool with screwed probe the process of metal extruding is more complex $[3,6,11,12]$.

The structure (Fig. 13) reveals a good metallic bonding between EN AC 43200 alloy layer (from the top) and material matrix of EN AW 6082 alloy. For many places in the weld structure from Figs. 10-12 


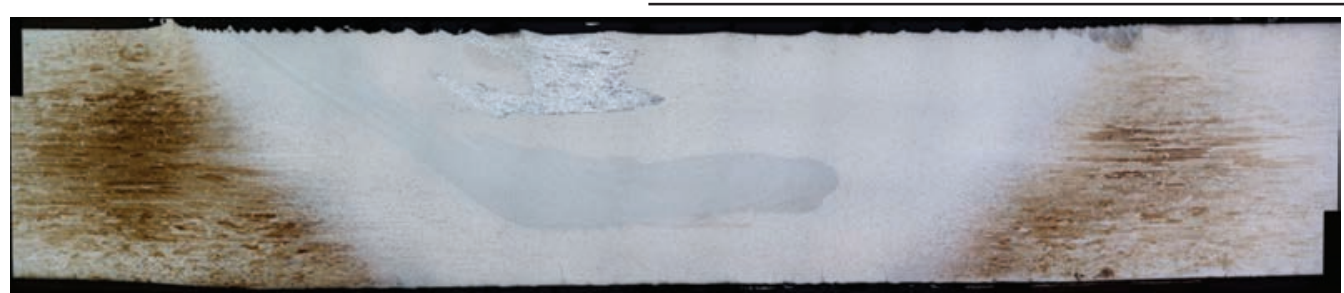

Fig. 10. Structure of FSW weld in case of location EN AC 43200 rod (A) on the advancing side (as in Fig. 9a). Welding parameters: $\omega=450 \mathrm{~min}^{-1}, \mathrm{~V}=224 \mathrm{~mm} / \mathrm{min}$. Triflute tool. Keller etching

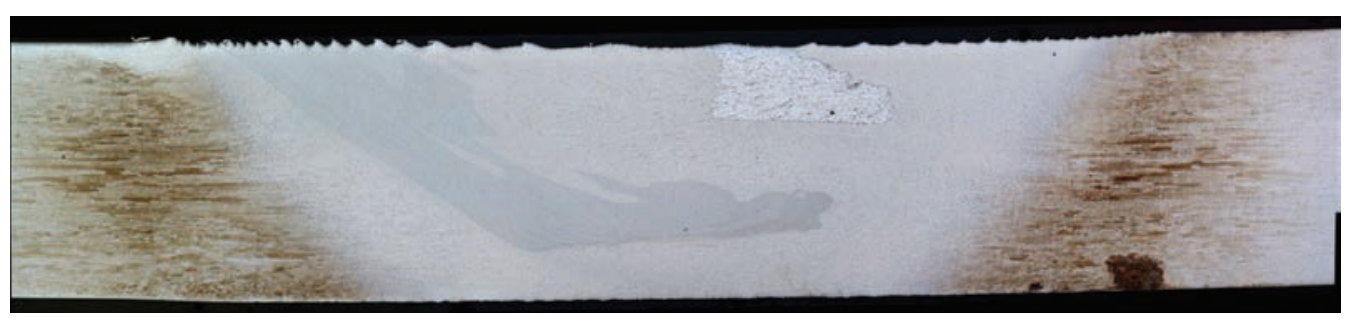

Fig. 11. Structure of a weld in case of location of a rod of EN AC 43200 on retreating side (as in Fig. 9b). Welding parameters: $\omega=$ $=450 \mathrm{~min}^{-1}, \mathrm{~V}=224 \mathrm{~mm} / \mathrm{min}$. Keller etching

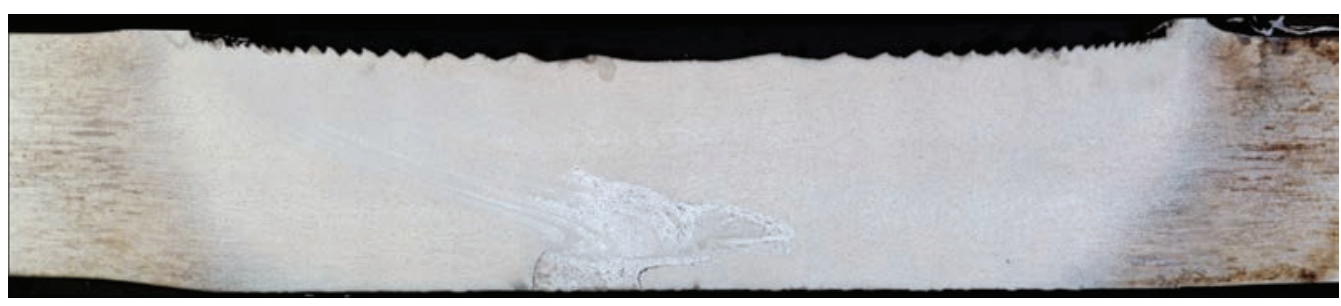

Fig. 12. Structure of a weld in case of location of a rod of EN AC 43200 in the root on the advancing side (as in Fig. 9c). Welding parameters: $\omega=450 \mathrm{~min}^{-1}, \mathrm{~V}_{\mathrm{zg}}=224 \mathrm{~mm} / \mathrm{min}$. Keller etching

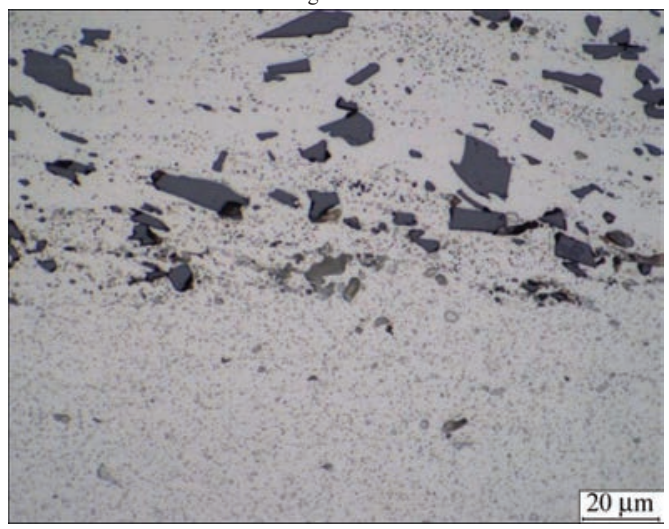

Fig. 13. Fragment of a structure from Fig. 9. Bonding of metal layer of EN AC 43200 with EN AW 6082 alloy

the SEM-EDS analysis was conducted. The exemplary results of the analysis are shown in Fig. 14.

The area subjected to the significant strains and deformations was tested from the viewpoint of

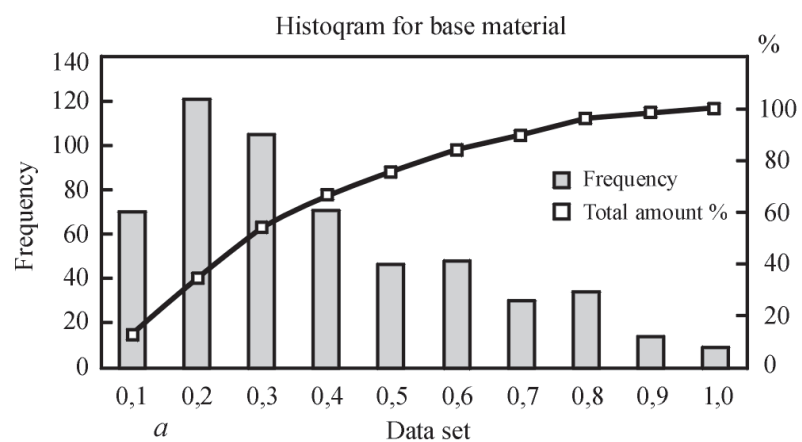

Fig. 15. The measurement of grain size in parent material of casting alloy (a) and in material subjected to the strains and deformations (b)
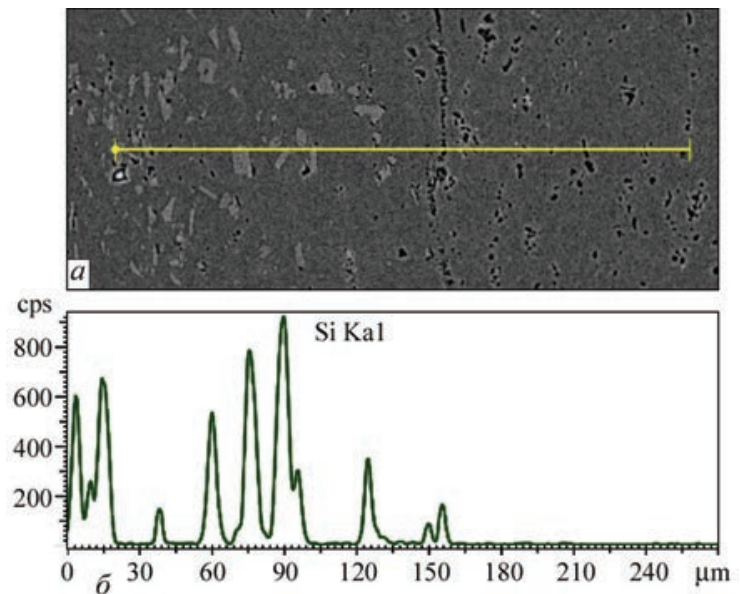

Fig. 14. Boundary between EN AC 43200 alloy (on the left side), and EN AW 6082 alloy (on the right side); a — line, along which the analysis of chemical content SEM-EDS was conducted; $b-$ Si concentration along measuring line

the average size of the particle and shape factor. In

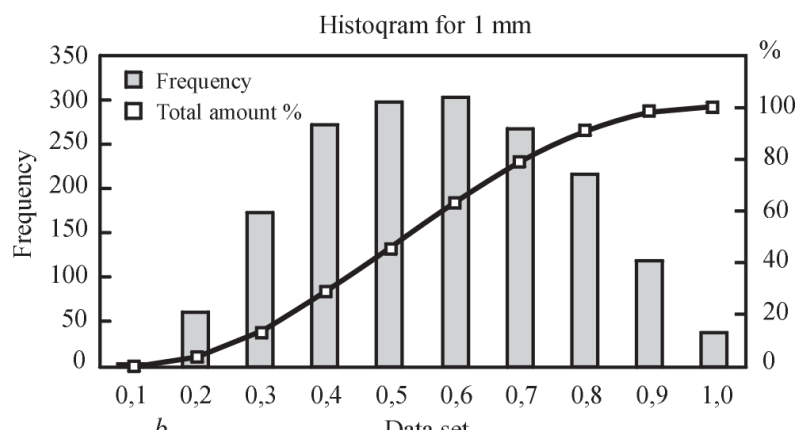




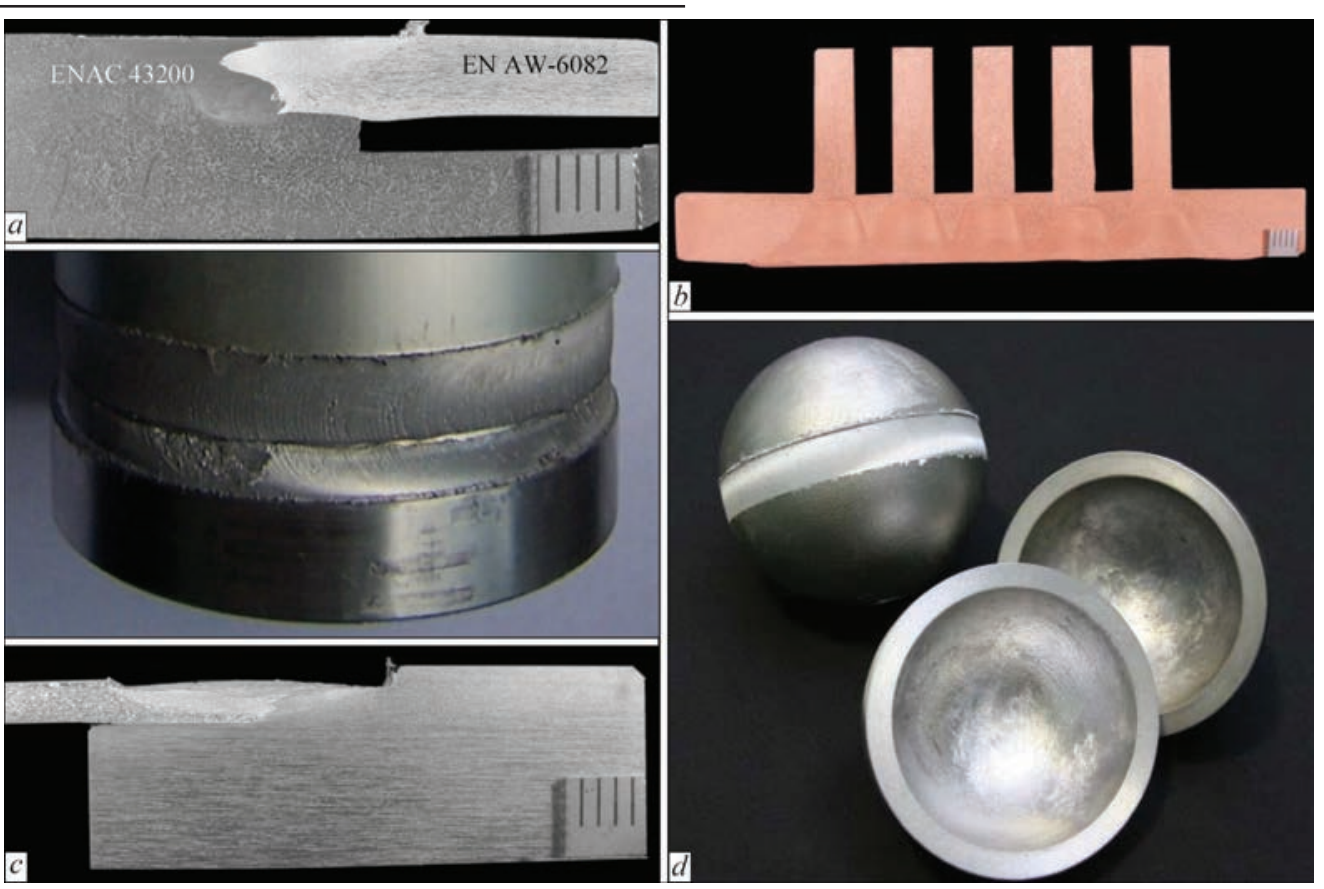

Fig. 16. Examples of the application of FSW process [12]: $a$ - heat exchanger cross-section; $b$ - cross-section of an electrical connector made of M1 copper; c — components and cross-section of a weld in pneumatic cylinder of EN AW-2017A alloy; d - Components of balls for check valves of EN AC 43200 alloy

Fig. 15 histograms of the particles occurrence frequency in separate intervals of shape factor are presented. In parent material (Fig. 15a) very elongated particles dominate $-12.8 \%$ particles have shape factor below 0.1 , and $54 \%$ particles below 0.3 . For the tested area of a weld (Fig. 15) only $13.5 \%$ particles have the shape factor below 0.3 , whereas the particles of shape factor between $0.3 \ldots 0.8$ are the dominant $(68.4 \%)$. The research results have indicated that plastic deformation occurring while welding caused very high refinement of particles and changed their shape towards particles being more equiaxial.

The results of conducted research into the process of friction welded joints forming together with testing of their mechanical properties were used while developing FSW process conditions for welding components in the industrial practice. Such elements, for which FSW technology was developed at Instytut Spawalnictwa, basing among other things on the research mentioned above, are the following (Fig.16): components of pneumatic cylinder of EN AW-2017A alloy, heat exchangers of EN AC 43200 casting alloy and EN AW-6082 alloy as well as copper M1, balls for check valves of EN AC 43200 casting alloy, M1 copper contact rails and others [13].

\section{Summary}

While using FSW process it is possible to join various materials, including materials of significantly different physical properties. During testing, application of two alloys being able to be joined but differing in chemical composition and properties, like EN AC 43200 casting alloy and wrought alloy
EN AW 6082, proved useful. Placing materials from the retreating or advancing side enables observation of the process of heating and creation of the weld structures. Casting alloy used as a marker made it possible to observe the process of metal movement around the tool and the structure of the FSW joint.

As it was revealed [6] during the FSW process the largest amount of heat is produced as the result of tool shoulder action, however the proper structure of a weld in the whole thickness of the components being joined, in case of elements thicker that approximately $2.0 \mathrm{~mm}$, depends on the shapes and dimensions of the tool probe and its movement. For thin elements the probe is not playing the crucial role in the process of the weld formation. The tool moving and plunging into the material starts to heat and plasticise various material zones. Heat in the welding process, as a result of good conduction is heating also material before a tool, what facilitates plunging a tool into the material preheated to the certain temperature.

The research revealed that with increasing the friction speed the friction factor $\mu$ is reduced during working of a tool on each tested material and in all temperature conditions.

At temperature higher than $400{ }^{\circ} \mathrm{C}$, i.e. in the temperature range observed in FSW process, for higher frictional speed the change of friction factor value along with changing temperature does not practically occur. This results in the fact that at higher frictional speeds such a friction conditions are stabilised in the friction interface, that the temperature of the plate (base) does not influence significantly the friction process and associated friction forces. At high temperature of 
the plates, friction forces are relatively low. For low frictional speeds, temperature has an impact on friction force value.

The above presented research revealed that during conducting typical FSW process the temperature of plates being welded has little influence on the friction torque. In turn, rotational speed of a tool influences it significantly. It can be however noticed, while analysing the research results, that tool rotational speed has an impact on the down force. During testing, it was not assumed that the process would be conducted at the same, constant down force. Down force value in this case is a resulting value and is associated with a tool leading in such a way, that the weld face is formed correctly.

As can be noticed, for growing frictional speeds of a tool, down force is being reduced. It is associated, as can be concluded, with heating of the material in the friction zone, which for higher frictional speeds is being heated more intensively, causing the reduction of mechanical properties of metal and consequently, the reduction of down force recorded by measuring head.

Thus, frictional speed has an impact on friction processes, it is associated with temperature of metal in friction zone and this metal temperature, in turn, influences in a certain way the down force of a tool (in a tool axis). However, temperature of plates fails to influence clearly the value of friction force (friction torque).

Beside temperature, which undoubtedly influences friction processes, the second factor which should be taken into consideration in the analysis of the processes occurring while forming of the FSW joint, is a layer of metal being modified using friction processes and undergoing plastic distortion.

By the action of a tool in the conditions of friction heating and upsetting, the metal layer in the direct vicinity of a tool undergoes thorough modification. Research revealed that it is a region of very high refinement of grains having a shape factor 0.4-0.7 (Fig. 15) and undergoing dynamic recrystallisation and/or healing.

The analysis of friction force courses (friction coefficient), structures of material layers being modified and temperature in the friction area has revealed that overall friction forces, recorded during testing (e.g. friction torque), more depend on the thickness of a layer undergoing modification and distortion, (i.e. internal friction) and in lower extend on external friction, that is on conditions in the friction interface: tool - welded metal. In turn, the thickness of a layer undergoing plastic deformation in which internal friction occurs, depends on friction speed. The higher friction speed the thinner layer [10].

The research into friction welding quality in a straight majority of cases shows, that metals coming from retreating and advancing side, modified with friction process and upset against each other on the retreating side, while movement backwards are joined correctly. Depending on the welding process parameters as well as applied tool and thickness of the plates being welded, the area of limited metal coherence can be located behind the tool on the advancing side $[10,12,14]$.

The manner of the metal transfer around the tool significantly influences the structure of FSW joint. As can be seen, at the specimens with included casting alloy, strongly heated and deformed material during extruding around the tool effectively recreated its previous localisation. Dissimilar physical properties of materials on both sides of a tool (advancing and retreating sides) proved not to prevent such a systematic placement of material after the process of extruding backwards.

Research into average size of the particles and the shape factor of the material subjected to the strains and deformations shown that FSW process caused very high refinement of particles and changed their shape towards particles being more equiaxial.

\section{References}

1. Thomas, W. M. Friction Stir Butt Welding. Int. Patent Application. PCT/GB92/02203.1991

2. (2010) Friction Stir Welding. From basics to applications. Woodhead Publishing Limited.

3. Mroczka, K., Dutkiewicz, J., Pietras, A. (2010) Characterization of friction stir welds of 6013 and 6013/2017A aluminium alloy sheets. Inżynieria Materiałowa, 31, 3.

4. Guohong Luan, Guang Li, Weibing Wang, Ju Kang (2010) The fundamental research of the friction flow welding. In: Proc. of 8th Int. Symp. on Friction Stir Welding (Germany, 18-20 May 2010).

5. Kumar, N, Yuan, W, Mishra, R.S. (2015) Friction stir welding of dissimilar alloys and materials. Butterworth-Heinemann (Elsevier), Oxford.

6. Hamilton, C., Kopyściański, M., Dymek, S., Wegglowska, A., Pietras, A. (2017) Microstructure of friction stir welded AlSi9Mg cast with 5083 and 2017A wrought aluminium alloys. J. of Mater. Eng. and Performance, 26(1).

7. PN-EN 10027-1:2007P: Systemy oznaczania stali - Część 1: Znaki stali.

8. PN-EN 1706:2010: Aluminium i stopy aluminium - Odlewy - Skład chemiczny i własności mechaniczne.

9. PN-EN 573-3:2010P: Aluminium i stopy aluminium - Skład chemiczny i rodzaje wyrobów przerobionych plastycznie Część 3: Skład chemiczny i rodzaje wyrobów.

10. Pietras, A. (2014) Praca Badawcza ST 330, Materials of Welding Research, Institute of Welding, Gliwice.

11. Mroczka, K., Pietras, A., Jura, J. (2016) Features of 2017A and AlSi9Mg aluminum alloys friction stir welded with rootside heating, Metall. Found. Eng., 42(2).

12. Mroczka, K. (2014) Charakterystyka mikrostruktury i właściwości zgrzein FSW wybranych stopów aluminiu. (Characterisation of the microstructure and properties of FSW welds of selected aluminium alloys). Wydawnictwo Naukowe UP, Kraków.

13. Pietras, A. et al. (2010-2015) Works of the Institute of Welding, Gliwice for industrial partners.

14. Węglowski, M.S., Pietras, A., Węglowska, A. (2009) Effect of welding parameters on mechanical and microstructural properties of Al 2024 joints produced by friction stir welding. J. of Kones Powertrain and Transport, 19(1). 


\title{
ТЕХНОЛОГІЯ ЗВАРЮВАННЯ ТЕРТЯМ 3 ПЕРЕМІШУВАННЯМ КОЛЬОРОВИХ МЕТАЛІВ — УМОВИ ПРОЦЕСУ ТА ПРИКЛАДИ ЗАСТОСУВАННЯ
}

\author{
А. ПІЕТРАС, А. ВЕГЛОВСЬКА, Б. РАМС
}

Інститут зварювання, 44-100, Глівіце, вул. Бл. Чеслава 16-18, Польща. E-mail: adam.pietras@is.gliwice.pl

Представлені умови зварювання та процес створення зварного шва зварюванням тертям з перемішуванням (FSW) елементів з кованих алюмінієвих сплавів та литого алюмінієвого сплаву. Дослідження проводилися в Інституті зварювання, Глівіце (Instytut Spawalnictwa), на устаткуванні FSW, обладнаному вертикально-фрезерним верстатом, пристосованим для процесу зварювання тертям. Вивчено вплив розміру та форми інструменту на процес пластифікації зварного матеріалу та формування металу шва за інструментом при різних параметрах зварювання. Під час досліджень було помічено, що сили і момент, що виникає при FSW жорсткість системи затискання впливають на температуру зони зварювання, пластичність матеріалу, фрагментацію часток і якість металу перемішування. На основі досліджень були обрані правильні умови зварювання та проведення процесу зварювання з використанням спеціально розроблених приладів. Показані зразки, виготовлені тертям з перемішуванням. Бібліогр. 14, Табл. 4, Рис. 16

Ключ ов і сл в в : зварювання тертям з перемімуванням, зварені та литі алюмінієві сплави, інструмент з міді

\section{ТЕХНОЛОГИЯ СВАРКИ ТРЕНИЕМ С ПЕРЕМЕШИВАНИЕМ ЦВЕТНЫХ МЕТАЛЛОВ — УСЛОВИЯ ПРОЦЕССА И ПРИМЕРЫ ПРИМЕНЕНИЯ}

\section{А. ПИЕТРАС, А. ВЕГЛОВСКА, Б. РАМС}

Институт сварки, 44-100, Гливице, ул. Бл. Чеслава 16-18, Польша. E-mail: adam.pietras@is.gliwice.pl

В статье представлены условия сварки и процесс создания сварки трением с перемешиванием (FSW) во время изготовления элементов из кованых алюминиевых сплавов и литого алюминиевого сплава. Исследования проводились в Институте сварки, Гливице (Instytut Spawalnictwa), на установке для FSW, оборудованной вертикальным фрезерным станком, приспособленным для сварки трением. Изучалось влияние размеров и форм инструмента на процесс пластификации свариваемого материала и формирования металла шва вслед за инструментом при различных параметрах сварки. В ходе исследований было замечено, что силы и крутящий момент, возникающие во время FSW, жесткость системы зажима, влияют на температуру зоны сварки, пластичность материала, фрагментацию частиц и качество металла перемешивания. На основе исследований были выбраны оптимальные условия сварки, эксперименты по сварке проводились с использованием специально разработанной аппаратуры. Показаны примеры сварных соединений, выполненных трением с перемешиванием. Библиогр. 14, табл. 4, Рис. 16.

Ключев ы е слова: сварка трением с перемешиванием, сварные и литые алюминиевые сплавы, медный инструмент

\section{Новая книга}

Физические процессы при сварке и обработке материалов. Теоретическое исследование, математическое моделирование, вычислительный эксперимент: Сб. статей и докладов под ред. акад. НАН Украины И.В. Кривцуна. - Киев: Международная Ассоциация «Сварка», 2018. - 642 с.

Сборник включает 86 статей и докладов сотрудников отдела физики газового разряда и техники плазмы Института электросварки им. Е. О. Патона НАН Украины, опубликованных за период 1978-2018 гг. В нем обобщен сорокалетний опыт научно-исследовательской деятельности отдела в области теоретического исследования и компьютерного моделирования фризических явлений, протекающих при дуговых, плазменных, лазерных и гибридных процессах сварки, наплавки и напыления покрытий. Может быть интересен и полезен ученым, инженерам и технологам, занимающимся проблемами дуговой, плазменной, лазерной и гибридной сварки и обработки материалов, а также аспирантам и студентам, изучающим теоретические основы сварочных и родственных процессов.

Сборник можно заказать в редакции журнала «Автоматическая сварка».

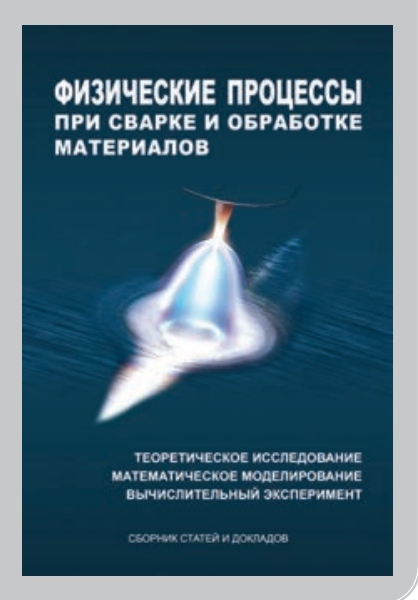

